\title{
KARAKTERISTIK BUDAYA NUSANTARA PADA TOKOH DAN SEMESTA \\ KOMIK NUSA V
}

\author{
Analisis Visual dengan Pendekatan Teori Semiotika Roland Barthes
}

\author{
Patra Aditia1 ${ }^{1}$, Bijaksana Prabawa² \\ Desain Komunikasi Visual, Fakultas Industri Kreatif, Telkom University, \\ Jl. Telekomunikasi no 1 Terusan Buah Batu Bandung 40257 Indonesia \\ patra.aditia@gmail.com
}

\begin{abstract}
Abstrak: Perkembangan komik dengan tema Nusantara sejak tahun 1990-an menimbulkan pertanyaan tentang identitas ke-Nusantara-an itu sendiri. Komik-komik tersebut ada yang mengedepankan sisi ke-Nusantara-an dari segi penokohan, latar, tema, ataupun peristilahan. Salah satu komik Indonesia yang cukup menarik perhatian di era kontemporer ini adalah Nusa V. Nusa V karya Sweta Kartika menampilkan lima tokoh yaitu Rangga Wira Prakoso, Rimba Kala Manthana, George Saa, Kanaya Meuthia, dan Renata Mokoginta. Dengan pendekatan teori semiotika Roland Barthes yang ditujukan bagi penelaahan tokoh-tokoh protagonis beserta istilah-istilah yang ada dalam semesta Nusa $V$, maka dapat diperoleh simpulan yaitu Nusa $V$ dibuat dengan intensi untuk menciptakan superhero Nusantara yang mengedepankan nilai-nilai lokal namun masih bisa diterima oleh publik global. Hal itu dilakukan dengan cara tidak membuat visualisasi yang tidak terlalu terasosiasikan pada nilai-nilai kelokalan (Nusantara), melainkan lebih pada arah yang universal; Nusa $V$ tetap mempertahankan nilai lokal melalui nama-nama para tokoh protagonisnya, beserta aspek-aspek peristilahan yang melekat padanya; Nusa V ingin agar para pembaca lebih meminati komik ini berdasarkan nilai-nilai ke-Nusantara-an dan bukan mengacu pada representasi visual semata, dan Nusa $V$ ingin menunjukkan aspek ke-Nusantara-an lewat istilah-istilah yang diturunkan dari bahasa Sansekerta yang akrab dengan tradisi Hindu di Nusantara.
\end{abstract}

Kata kunci: Komik, Nusa V, Semiotik, Nusantara, Lokal

Abstract: Since 1990s, Nusantara as a theme on Indonesian comics raises questions about the identity of Nusantara itself. There are comics that uses it as characteristics in terms of characterization, setting, theme, or terminology. One of the interesting Indonesian comics in this contemporary era is Nusa V. Created by Sweta Kartika, the story present five protagonist characters; Rangga Wira Prakoso, Rimba Kala Manthana, George Saa, Kanaya Meuthia, and Renata Mokoginta. In this research, Roland Barthes's semiotic theory used at examining the protagonists and the terms that used in the Nusa V universe, 
a conclusion can be obtained that Nusa $V$ is made with the intention to create a Nusantara superhero that consist local values but still can be accepted by global public. The characters design is not too associated with Nusantara visual characteristics, but rather more in a universal direction. Instead, Nusa $V$ retains local values through the names of its protagonists, along with the terminology attached to them. Nusa $V$ engage the readers to be more interested in this comic based on Nusantara values, as its trying to show Nusantara through Sanskrit terms that are familiar with Hindu tradition, not referring to visual representation alone.

Keywords: Comic, Nusa V, Semiotics, Nusantara, Local

\section{PENDAHULUAN}

Kemunculan komik pertama di Indonesia digadang dimulai ketika terbitnya komik Put-On di harian Sin Po. Komik karya Kho Wan Gie ini terbit dalam format strip dari tahun 1930 hingga berakhir pada tahun 1965 ketika awal mula kekuasaan Orde Baru. Berjumlah ratusan episode, Put-On berkisah tentang keseharian etnis Tionghoa di Indonesia yang dikemas dengan gaya yang lucu dan kocak. Menurut Sheila Rooswitha dan Peter van Dongen dalam Indonesian Comics 1929-2017: A Chronological History (2018), Komik Put-on digemari pada saat itu karena muncul di tengah serbuan komik asing seperti Flash Gordon, Superman, dan Tarzan. Puton memberi nuansa baru yang segar, dengan mengangkat ekspresi-ekspresi lokal yang dekat dengan keseharian.

Komik yang mengisahkan tentang wayang muncul pada sekitar tahun 1950-an. Wayang sendiri sebagai sebuah kesenian sebelumnya sudah akrab di masyarakat Nusantara lewat beragam bentuk pagelaran seperti wayang kulit, wayang golek, dan wayang orang. Tema ini langsung meraih popularitas karena keakraban tokoh dan cerita dengan pembacanya. Komikus-komikus seperti R. A. Kosasih dan Ardisoma tidak hanya menceritakan ulang epos-epos populer adaptasi dari India seperti seperti Ramayana dan Mahabharata, namun juga membuat lakon-lakon pedalangan karya Pujangga dan seniman wayang lokal (Rooswitha \& van Dongen, 2018). Komik wayang tersebut meraih popularitas 
dengan cepat karena tema yang sudah akrab sebelumnya serta membawa ajaran moral yang positif.

Pasca komik wayang, komik romansa menjadi primadona di tahun 1960an. Komik romansa bercerita tentang kisah cinta pemuda-pemudi yang biasanya mengambil latar di kota besar. Kisah ini kerap dibumbui dengan seksualitas sehingga menuai reaksi keras dari para orang tua yang menganggap bahwa komik adalah pengaruh buruk bagi generasi muda di Indonesia. Razia hingga pembakaran menjadi bagian dari reaksi masyarakat terhadap komik-komik yang waktu itu dirasa kurang mendidik. Pemerintah kota Semarang bahkan membakar komik yang terbit karena dirasa sebagai usaha kaum neokolonial merusak remaja (Bonneff, 1998)

Pengaruh negatif dalam komik ini coba dihalau melalui komik silat dan superhero pada sekitar tahun 1970-an. Dua tema ini mendapatkan respons positif dari pembaca karena memuat nilai-nilai lokal, dari mulai latar cerita yang mengambil tempat-tempat di Indonesia hingga ekspresi-ekspresi yang dipenuhi ciri khas budaya Nusantara termasuk misalnya terkait sopan santun. Komik di Indonesia bisa dibilang mati suri pada periode 1980-an sampai 1990-an. Komik terjemahan dari Eropa, Amerika, Hong kong, dan Jepang mengisi kekosongan komik terbitan lokal. Sementara komikus lokal lebih banyak membuat kisah dengan tokoh impor dari kartun dan fantasi Jepang yang populer lewat video Betamax seperti Voltus, Megaloman, dan God Sigma.

Di kegiatan Pasar Seni ITB yang diadakan tahun 1995, komik Indonesia mendapatkan angin segar dengan kemunculan komik Caroq karya Thoriq yang diterbitkan lewat bendera Qomik Nasional (Rooswitha \& van Dongen, 2018). Bercerita tentang Ongko, supir taksi yang mempunyai alter ego seorang superhero bernama Caroq yang bersenjatakan dua bilah celurit. Caroq dikenal karena 
gambarnya yang mengadaptasi komik Amerika namun latar tempat dan idiom bahasanya masih khas Indonesia. Selain Caroq, Qomik Nasional juga menerbitkan Kapten Bandung karya Anto Motulz (Ahmad dkk, 2006).

Seiring berkembangnya teknologi digital dan media sosial, komik Indonesia mengalami perkembangan secara format, cerita, maupun distribusi. Format komik yang sebelumnya berupa buku yang dicetak kini berkembang menjadi format digital seperti misalnya komik pindai, komik interaktif, hingga berbasiskan aplikasi. Walaupun terjadi pergantian generasi komikus, upaya mengangkat nilai-nilai lokal menjadi sebuah upaya positif yang selalu muncul medan sosial komik Indonesia. Misalnya, Erfan Fajar mengangkat setan-setan Indonesia dengan latar futuristik dalam Manungsa atau Alex Irzaqi menafsirkan kisah kepahlawanan di zaman Majapahit lewat Dharmaputra Winehsuka.

Hal yang kerap muncul dalam komik-komik terbitan lokal adalah upaya memasukkan budaya Nusantara dalam komik-komiknya; dari mulai, latar kejadian, efek suara, cerita, sampai perancangan tokoh. Salah satu komik yang mengangkat budaya lokal dalam komiknya adalah Nusa V karya Sweta Kartika. Nusa V (dibaca Nusa Five) adalah hasil kerjasama antara Padma Pusaka Nusantara; sebuah perusahaan kreatif di Indonesia, dengan Shogakukan Asia. Di Indonesia, Nusa V diterbitkan oleh Re: On Comics per bab secara bulanan, dilanjutkan format buku di akhir tahun 2018. Selain di Indonesia, Nusa V juga diterbitkan di Singapura oleh penerbit Shogakukan.

Nusa $V$ menarik untuk diteliti sebagai salah satu model untuk memunculkan budaya lokal dalam komik Indonesia. Penelitian ini fokus pada tokoh protagonis karena keragaman visual serta tokoh yang menjadi sentral cerita. Diharapkan lewat penelitian ini, model presentasi untuk memunculkan budaya lokal mampu dikembangkan serta menjadi salah satu acuan untuk memperluas 
khazanah visual dan tekstual mengenai komik di Indonesia.

\section{METODE PENELITIAN}

Penelitian ini adalah penelitian kualitatif dengan paradigma kritis. Data diperoleh melalui observasi terhadap visual dalam komik Nusa $V$ dan studi literatur mengenai teori-teori yang dianggap relevan untuk menganalisis. Teori yang dianggap relevan, dalam hal ini, adalah pendekatan semiotika dari Roland Barthes. Barthes dalam bukunya yang berjudul Elemen-Elemen Semiologi (2012) dan Membedah Mitos-Mitos Budaya Massa (2007) melihat lebih jauh mengenai konsep penandaan pada tataran yang lebih dalam (konotatif), dimana sebelumnya Saussure melihat terutama pada tataran denotatif. Roland Barthes melihat bahasa sebagai sebuah sistem tanda yang mencerminkan asumsi-asumsi dari masyarakat tertentu dalam waktu tertentu. Sebagaimana pandangan Saussure, Barthes juga meyakini bahwa antara penanda dan petanda tidak terbentuk secara alamiah, melainkan bersifat arbitrer. Bila Saussure hanya menekankan pada penandaan dalam tataran denotatif, maka Barthes menyempurnakan semiologi Saussure dengan mengembangkan sistem penandaan pada tingkat konotatif. Barthes juga melihat aspek lain dari penandaan, yaitu mitos yang menandai suatu masyarakat.

\begin{tabular}{|c|c|c|}
\hline $\begin{array}{c}1 . \\
\text { Signifier } \\
\text { (penanda) }\end{array}$ & $\begin{array}{c}2 . \\
\text { Signified } \\
\text { (petanda) }\end{array}$ & \\
\hline \multicolumn{3}{|c|}{$\begin{array}{c}\text { 3. } \\
\text { Denotative Sign } \\
\text { (tanda denotatif) }\end{array}$} \\
\hline \multicolumn{2}{|c|}{$\begin{array}{c}4 . \\
\text { Connotative Signifier } \\
\text { (penanda konotatif) }\end{array}$} & $\begin{array}{c}5 . \\
\text { Connotative } \\
\text { Signified } \\
\text { (petanda konotatif) }\end{array}$ \\
\hline \multicolumn{2}{|c|}{$\begin{array}{c}6 . \\
\text { Connotative Sign } \\
\text { (tanda konotatif) }\end{array}$} & \\
\hline \multicolumn{3}{|c|}{ Gambar 1. Peta Tanda Barthes } \\
\hline
\end{tabular}


Dalam peta tanda yang dikembangkan Barthes (Gambar 1), maka dapat dilihat bagaimana tanda denotatif (3) terbentuk dari relasi antara penanda (1) dan petanda (2). Akan tetapi, pada saat bersamaan, tanda denotatif juga menjadi sebuah penanda konotatif (4). Denotasi dalam pandangan Barthes merupakan tataran pertama yang maknanya bersifat tertutup. Tataran denotasi menghasilkan makna yang lugas, langsung, dan pasti. Denotasi merupakan makna yang sebenarbenarnya atau harfiah, yang disepakati bersama secara sosial, yang rujukannya pada realitas.

Tanda konotatif merupakan sebuah tanda yang dibangun melalui relasi dimana penandanya mempunyai makna yang implisit (tersamar), tidak langsung, dan tidak pasti, artinya terbuka kemungkinan terhadap penafsiran-penafsiran baru. Dalam semiologi Barthes, relasi dalam tanda denotatif dijelaskan sebagai sistem signifikansi tingkat pertama, sedangkan tanda konotatif merupakan sistem signifikansi tingkat kedua. Denotasi dapat dikatakan merupakan makna objektif yang tetap, sedangkan konotasi merupakan makna subjektif dan bervariasi.

Lebih lanjut, dalam kerangka Barthes konotasi identik dengan operasi ideologi, yang disebutkannya sebagai mitos dan berfungsi untuk mengungkapkan dan memberikan pembenaran bagi nilai-nilai dominan yang berlaku dalam suatu periode tertentu. Mitos menurut Barthes juga merupakan sebuah sistem pemaknaan tataran kedua.

Mitos dalam pandangan Barthes berbeda dengan konsep mitos dalam arti umum. Barthes mengemukakan mitos adalah bahasa, maka mitos adalah sebuah sistem komunikasi dan mitos adalah sebuah pesan. Dalam uraiannya, ia mengemukakan bahwa mitos dalam pengertian khusus ini merupakan perkembangan dari konotasi. Konotasi yang sudah terbentuk lama di masyarakat itulah mitos. Barthes mengatakan bahwa mitos merupakan sistem semiologis, 
yakni sistem tanda-tanda yang dimaknai manusia. Mitos dapat dikatakan sebagai produk kelas sosial yang sudah memiliki suatu dominasi.

Teori semiotika yang telah dipaparkan di atas kemudian digunakan untuk membaca tanda-tanda dalam komik Nusa V, seperti tampilan fisik dari para tokoh protagonis, karakteristik yang ditampilkan, serta istilah-istilah yang digunakan. Setelah semua aspek dianalisis, maka akan dapat ditarik kesimpulan mengenai nilai budaya Nusantara dalam tokoh protagonis komik Nusa $\mathrm{V}$.

\section{HASIL DAN DISKUSI}

Penelitian dilakukan berdasarkan teori semiotika Roland Barthes untuk menelaah aspek semesta dan karakter dalam latar adegan Nusa $\mathrm{V}$.

\section{Kajian Tokoh}

Aspek citra akan dianalisis dengan menggunakan analisis matriks. Bagian baris diisi tahapan-tahapan analisis yang terdiri dari deskripsi, analisis, interpretasi, dan penilaian, sementara bagian kolom berisi nama-nama para tokoh protagonis dalam Nusa V. 


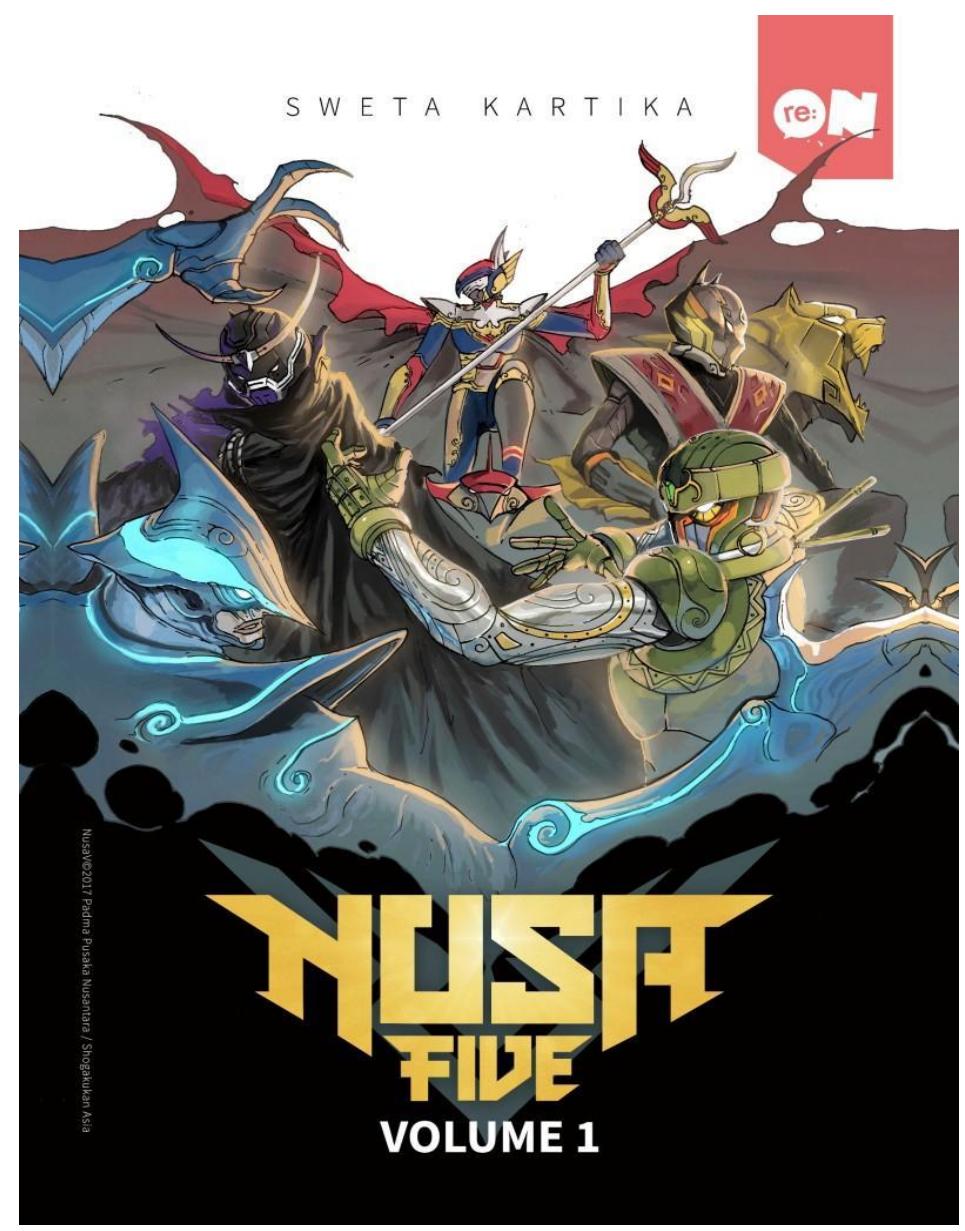

Gambar 2. Sampul komik Nusa V volume 1

Sumber: Sweta Kartika, 2019

Tokoh-tokoh tersebut adalah Rangga Wira Prakoso, Kanaya Meuthia, Rimba Kala Manthana, Renata Mokoginta, dan George Saa. Sementara gambar yang dianalisis diuraikan pada Tabel 1 sebagai berikut: 
Tabel 1: Analisis Tokoh Nusa V

\begin{tabular}{|c|c|c|c|c|c|}
\hline & 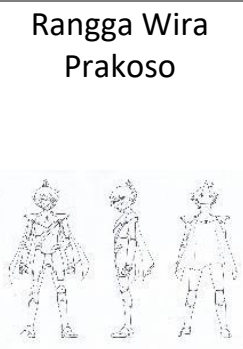 & 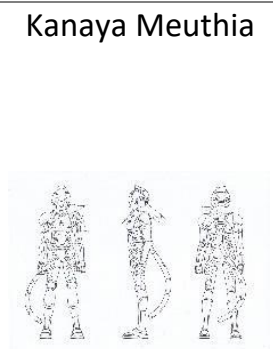 & 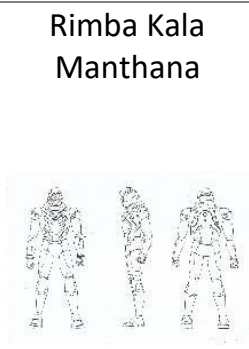 & $3+\frac{6}{4}$ & 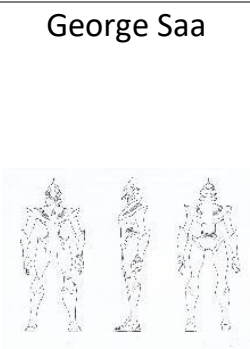 \\
\hline 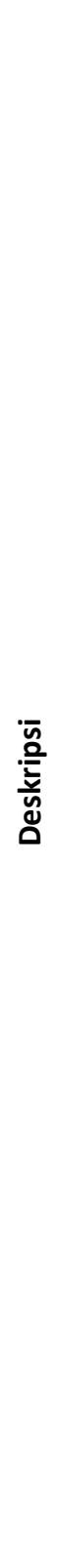 & $\begin{array}{l}\text { Kostum } \\
\text { dominan biru } \\
\text { dan merah, } \\
\text { Memakai jubah } \\
\text { dan mahkota } \\
\text { serta mem- } \\
\text { bawa tongkat } \\
\text { dengan mata } \\
\text { tombak ber- } \\
\text { bentuk kujang } \\
\text { dan sayap. } \\
\text { Seluruh tubuh } \\
\text { terlindungi } \\
\text { pakaian ber- } \\
\text { bahan kulit dan } \\
\text { ornamen } \\
\text { rangka luar } \\
\text { (armor) dengan } \\
\text { motif tradisi- } \\
\text { onal Jawa. } \\
\text { Rangga } \\
\text { mengendarai } \\
\text { semacam robot } \\
\text { yang berbentuk } \\
\text { burung ber- } \\
\text { warna merah } \\
\text { dan emas. }\end{array}$ & $\begin{array}{l}\text { Kostum dominan } \\
\text { merah marun, } \\
\text { kuning dan hitam. } \\
\text { Pelindung kepala } \\
\text { dengan kesan } \\
\text { wajah harimau. } \\
\text { Rompi dengan } \\
\text { ornamen kuning } \\
\text { yang melebar } \\
\text { pada bagian } \\
\text { bahu. } \\
\text { Di leher terdapat } \\
\text { kalung perak. } \\
\text { Badan terbungkus } \\
\text { pakaian dengan } \\
\text { rangka luar } \\
\text { berwarna hitam } \\
\text { Gelang emas } \\
\text { dibagian bawah } \\
\text { siku. } \\
\text { Membawa robot } \\
\text { berbentuk } \\
\text { harimau } \\
\text { berwarna emas. }\end{array}$ & $\begin{array}{l}\text { Kostum } \\
\text { dominan warna } \\
\text { hijau, perak, } \\
\text { emas, dan } \\
\text { jingga. } \\
\text { Tubuh dilapisi } \\
\text { rangka luar } \\
\text { dengan motif } \\
\text { segitiga dan ulir. } \\
\text { Mengenakan } \\
\text { pelindung } \\
\text { kepala yang } \\
\text { menutupi wajah } \\
\text { dengan batu } \\
\text { berwarna hijau } \\
\text { pada bagian } \\
\text { dahi dan anting } \\
\text { bulat berwarna } \\
\text { emas pada } \\
\text { kedua bagian } \\
\text { telinga. } \\
\text { Pada bagian } \\
\text { bahu terdapat } \\
\text { ornamen rangka } \\
\text { luar bulat } \\
\text { berwarna hijau. }\end{array}$ & $\begin{array}{l}\text { Kostum dominan } \\
\text { ungu dan hitam. } \\
\text { Tubuh tertutup } \\
\text { jubah ungu } \\
\text { kehitaman } \\
\text { dengan tali putih } \\
\text { yang melilit di } \\
\text { pergelangan } \\
\text { tangan. } \\
\text { Kepalanya } \\
\text { tertutup oleh } \\
\text { pelindung kepala } \\
\text { hitam dengan } \\
\text { kesan wajah } \\
\text { kerbau dan } \\
\text { tanduk pada } \\
\text { bagian dahi } \\
\text { dengan batu ungu } \\
\text { bagian tengah- } \\
\text { nya. }\end{array}$ & $\begin{array}{l}\text { Kostum } \\
\text { dominan biru } \\
\text { dengan kesan } \\
\text { menyerupai hiu. } \\
\text { Ada pelindung } \\
\text { berbentuk sirip } \\
\text { dengan } \\
\text { ornamen pada } \\
\text { bagian atas dan } \\
\text { warna biru } \\
\text { muda di } \\
\text { sekelilingnya } \\
\text { Telinga } \\
\text { menyerupai } \\
\text { lubang insang, } \\
\text { ada ruang } \\
\text { terbuka pada } \\
\text { daerah mulut } \\
\text { dan pipi. } \\
\text { Seluruh tubuh } \\
\text { dilindungi } \\
\text { pakaian dengan } \\
\text { rangka luar } \\
\text { dengan bagian } \\
\text { bahu yang } \\
\text { melebar dan } \\
\text { lancip ke atas. } \\
\text { Bagian luar } \\
\text { pakaian } \\
\text { terdapat } \\
\text { ornamen } \\
\text { berwarna biru } \\
\text { menyala berupa } \\
\text { garis dan ulir. } \\
\text { Tangan tertutup } \\
\text { oleh sarung } \\
\text { dengan ujung- } \\
\text { ujung jari tajam. }\end{array}$ \\
\hline
\end{tabular}




\begin{tabular}{|c|c|c|c|c|c|}
\hline$\frac{\frac{n}{n}}{\frac{\underline{n}}{\sqrt[N]{0}}}$ & $\begin{array}{l}\text { Dengan } \\
\text { deskripsi } \\
\text { karakter yang } \\
\text { mengatakan } \\
\text { bahwa tokoh } \\
\text { Rangga Wira } \\
\text { Prakoso } \\
\text { merepresentasi- } \\
\text { kan Pulau Jawa, } \\
\text { pada dasarnya } \\
\text { tidak ada } \\
\text { sedikitpun } \\
\text { elemen visual } \\
\text { mencirikan } \\
\text { sesuatupun } \\
\text { yang berasal } \\
\text { dari Pulau Jawa. } \\
\text { Kita tahu bahwa } \\
\text { Rangga Wira } \\
\text { Prakoso berasal } \\
\text { dari Jawa hanya } \\
\text { dari nama dan } \\
\text { karakter yang } \\
\text { diperlihatkan } \\
\text { dalam komik } \\
\text { (mendapat } \\
\text { kekuatan dari } \\
\text { Elang Jawa). }\end{array}$ & $\begin{array}{l}\text { Pada unsur-unsur } \\
\text { visual yang } \\
\text { terdapat pada } \\
\text { Kanaya Meuthia } \\
\text { yang Digambar- } \\
\text { kan berasal dari } \\
\text { Sumatra, ter- } \\
\text { dapat kesan } \\
\text { visual harimau } \\
\text { dari beberapa } \\
\text { contoh pose } \\
\text { beserta elemen } \\
\text { visual berupa } \\
\text { citra "kuping" } \\
\text { yang digunakan } \\
\text { sebagai mahkota. } \\
\text { Elemen visual ini } \\
\text { merepresentasi- } \\
\text { kan "Harimau } \\
\text { Sumatera" } \\
\text { sebagai sumber } \\
\text { kekuatan Kanaya } \\
\text { Meuthia. }\end{array}$ & $\begin{array}{l}\text { Pada unsur- } \\
\text { unsur visual } \\
\text { yang ada pada } \\
\text { Rimba Kala } \\
\text { Manthana, } \\
\text { warna hijau bisa } \\
\text { diasosiasikan } \\
\text { dengan "hutan" } \\
\text { yang menjadi } \\
\text { salah satu ciri } \\
\text { khas yang } \\
\text { melekat dengan } \\
\text { Pulau } \\
\text { Kalimantan. } \\
\text { Visual Orang } \\
\text { Utan biasanya } \\
\text { turut melekat } \\
\text { dengan Rimba } \\
\text { Kala Manthana } \\
\text { sebagai sumber } \\
\text { kekuatannya. } \\
\text { Hal tersebut } \\
\text { memberi kesan } \\
\text { kuat tersendiri } \\
\text { bagi Rimba Kala } \\
\text { Manthana. }\end{array}$ & $\begin{array}{l}\text { Renata } \\
\text { Mokoginta tidak } \\
\text { memiliki elemen } \\
\text { visual yang } \\
\text { terlampau } \\
\text { mengasosiasikan } \\
\text { dirinya dengan } \\
\text { Pulau Sulawesi, } \\
\text { kecuali deskripsi } \\
\text { yang menunjuk- } \\
\text { kan bahwa ia } \\
\text { mempunyai } \\
\text { kekuatan dari } \\
\text { Anoa yang nota- } \\
\text { bene merupakan } \\
\text { hewan dari } \\
\text { Sulawesi. }\end{array}$ & $\begin{array}{l}\text { George Saa } \\
\text { mengasosiasi- } \\
\text { kan diri dengan } \\
\text { Papua lewat } \\
\text { elemen visual } \\
\text { berupa kulit } \\
\text { agak gelap dan } \\
\text { rambut ikal } \\
\text { yang merupa- } \\
\text { kan salah satu } \\
\text { ciri fisik orang } \\
\text { Papua yang } \\
\text { menjadi bagian } \\
\text { dari ras } \\
\text { Melanesia. } \\
\text { Sementara } \\
\text { elemen lainnya } \\
\text { tidak ada yang } \\
\text { khusus, kecuali } \\
\text { deskripsi } \\
\text { tentang hiu } \\
\text { gergaji yang jadi } \\
\text { sumber } \\
\text { kekuatannya. } \\
\text { Hiu gergaji } \\
\text { sendiri identik } \\
\text { dengan hewan } \\
\text { khas Papua. }\end{array}$ \\
\hline 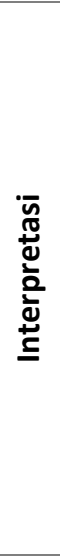 & $\begin{array}{l}\text { Tidak terlihat } \\
\text { upaya dari } \\
\text { komikus untuk } \\
\text { mengasosiasi- } \\
\text { kan tokoh } \\
\text { Rangga Wira } \\
\text { Prakoso dengan } \\
\text { elemen visual } \\
\text { yang } \\
\text { berhbungan } \\
\text { secara langsung } \\
\text { dengan konsep } \\
\text { "Jawa". }\end{array}$ & $\begin{array}{l}\text { Tidak terlihat } \\
\text { upaya dari } \\
\text { komikus untuk } \\
\text { mengasosiasikan } \\
\text { tokoh Kanaya } \\
\text { Meuthia dengan } \\
\text { elemen visual } \\
\text { yang berhubung- } \\
\text { an secara } \\
\text { langsung dengan } \\
\text { konsep } \\
\text { "Sumatra". }\end{array}$ & $\begin{array}{l}\text { Tidak terlihat } \\
\text { upaya dari } \\
\text { komikus untuk } \\
\text { mengasosiasi- } \\
\text { kan tokoh } \\
\text { Rimba Kala } \\
\text { Manthana } \\
\text { dengan elemen } \\
\text { visual yang } \\
\text { berhubungan } \\
\text { secara langsung } \\
\text { dengan konsep } \\
\text { "Kalimantan". }\end{array}$ & $\begin{array}{l}\text { Tidak terlihat } \\
\text { upaya dari } \\
\text { komikus untuk } \\
\text { mengasosiasikan } \\
\text { tokoh Renata } \\
\text { Mokoginta } \\
\text { dengan elemen } \\
\text { visual yang } \\
\text { berhubungan } \\
\text { secara langsung } \\
\text { dengan konsep } \\
\text { "Sulawesi". }\end{array}$ & $\begin{array}{l}\text { Tidak terlihat } \\
\text { upaya dari } \\
\text { komikus untuk } \\
\text { mengasosiasi- } \\
\text { kan tokoh } \\
\text { George Saa } \\
\text { dengan elemen } \\
\text { visual yang } \\
\text { berhubungan } \\
\text { secara langsung } \\
\text { dengan konsep } \\
\text { "Papua". }\end{array}$ \\
\hline 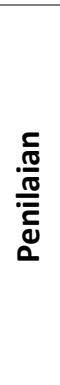 & $\begin{array}{l}\text { Elemen } \\
\text { kelokalan tidak } \\
\text { ditonjolkan } \\
\text { untuk menim- } \\
\text { bulkan kesan } \\
\text { universal dan } \\
\text { menghindari } \\
\text { stereotip. }\end{array}$ & $\begin{array}{l}\text { Elemen kelokalan } \\
\text { tidak ditonjolkan } \\
\text { untuk menimbul- } \\
\text { kan kesan } \\
\text { universal dan } \\
\text { menghindari } \\
\text { stereotip. }\end{array}$ & $\begin{array}{l}\text { Elemen } \\
\text { kelokalan tidak } \\
\text { ditonjolkan } \\
\text { untuk menim- } \\
\text { bulkan kesan } \\
\text { universal dan } \\
\text { menghindari } \\
\text { stereotip. }\end{array}$ & $\begin{array}{l}\text { Elemen kelokalan } \\
\text { tidak ditonjolkan } \\
\text { untuk menimbul- } \\
\text { kan kesan } \\
\text { universal dan } \\
\text { menghindari } \\
\text { stereotip. }\end{array}$ & $\begin{array}{l}\text { Elemen } \\
\text { kelokalan tidak } \\
\text { ditonjolkan } \\
\text { untuk } \\
\text { menimbulkan } \\
\text { kesan universal } \\
\text { dan } \\
\text { menghindari } \\
\text { stereotip. }\end{array}$ \\
\hline
\end{tabular}


Berdasarkan butir-butir yang telah dipaparkan dalam tabel di atas, maka hasil analisis menunjukkan bahwa para kostum dan atribut lainnya yang melekat pada tokoh-tokoh protagonis dalam Nusa V, tidak ada elemen kelokalan atau keNusantara-an yang ditonjolkan secara langsung. Penilaian ini mengarah pada upaya untuk menimbulkan kesan universal dan menghindari stereotip.

\section{Kajian Semesta}

Teori semiotika Roland Barthes ini akan lebih menelaah pada istilah-istilah yang ada pada semesta atau universe di Nusa V. Istilah-istilah itu akan dibagi ke dalam tiga tingkatan semiotika Roland Barthes yaitu denotasi, konotasi, dan mitos.

Tabel 2: Analisis Semesta Nusa V

\begin{tabular}{|c|c|c|c|}
\hline Nama & Denotasi & Konotasi & Mitos \\
\hline Bumi Mercapada & $\begin{array}{l}\text { Dunia nyata, tempat } \\
\text { makhluk hidup, bumi. }\end{array}$ & $\begin{array}{ll}\text { Lokasi menara } & \text { kristal } \\
\text { sumber } & \text { energi } \\
\text { kehidupan } & \\
\end{array}$ & \multirow{10}{*}{$\begin{array}{l}\text { Nusa V ingin menunjuk- } \\
\text { kan aspek ke-Nusantara- } \\
\text { an lewat istilah-istilah } \\
\text { yang diturunkan dari } \\
\text { bahasa Sansekerta yang } \\
\text { akrab dengan tradisi } \\
\text { Hindu di Nusantara. }\end{array}$} \\
\hline Segitiga Trimatra & Segitiga tiga dimensi. & Sebentuk jurus & \\
\hline Sandekala & Pergantian waktu. & $\begin{array}{l}\text { Pasukan Kelana, prajurit } \\
\text { kegelapan }\end{array}$ & \\
\hline Kelana & $\begin{array}{l}\text { Mengembara, perjalanan } \\
\text { tanpa tujuan tertentu. }\end{array}$ & $\begin{array}{lr}\text { Tokoh antagonis } \\
\text { (penjagarang } \\
\text { dimensi energi) }\end{array}$ & \\
\hline Pandita & Bijaksana & $\begin{array}{l}\text { Tokoh protagonist } \\
\text { (penjaga gerbang } \\
\text { dimensi energi) }\end{array}$ & \\
\hline Ganendra & Pasukan dewa & $\begin{array}{l}\text { Lima prajurit Pandita, } \\
\text { setengah manusia } \\
\text { setengah binatang. }\end{array}$ & \\
\hline Jawadwipa & $\begin{array}{l}\text { Nama pulau Jawa di zaman } \\
\text { dulu. }\end{array}$ & $\begin{array}{l}\text { Energi yang melingkupi } \\
\text { Rangga, penjaga } \\
\text { Jawadwipa, energi dari } \\
\text { gunung berapi }\end{array}$ & \\
\hline Barunadwipa & $\begin{array}{l}\text { Nama kuno untuk } \\
\text { Kalimantan atau Borneo. }\end{array}$ & $\begin{array}{l}\text { Energi yang melingkupi } \\
\text { Rimba, energi hutan dan } \\
\text { pohon. }\end{array}$ & \\
\hline Swarnadwipa & $\begin{array}{l}\text { Nama Pulau Sumatera } \\
\text { zaman dulu, yang artinya } \\
\text { pulau yang dipenuhi } \\
\text { tambang emas. }\end{array}$ & $\begin{array}{l}\text { Energi yang melingkupi } \\
\text { Kanaya, energi leluhur } \\
\text { yang memberi kekuatan } \\
\text { saat perang. }\end{array}$ & \\
\hline Kalvatar & Kekuatan agung. & $\begin{array}{l}\text { Pusat energi pembentuk } \\
\text { makhluk hidup. }\end{array}$ & \\
\hline
\end{tabular}


Berdasarkan butir-butir yang telah dipaparkan dalam tabel 2 di atas, maka hasil analisis menunjukkan bahwa aspek ke-Nusantara-an dalam komik Nusa $\mathrm{V}$ ditonjolkan melalui peristilahan-peristilahan yang muncul dalam semestanya. Peristilahan-peristilahan yang dianggap ke-Nusantara-an tersebut merupakan dengan bahasa Sansekerta yang erat kaitannya dengan tradisi Hindu di Nusantara.

\section{KESIMPULAN}

Berdasarkan pembahasan yang dilakukan menurut pemikiran semiotika dari Roland Barthes, maka dapat diambil simpulan bahwa Nusa V dibuat dengan intensi untuk menciptakan superhero Nusantara yang mengedepankan nilai-nilai lokal namun masih bisa diterima oleh publik global. Hal itu dilakukan dengan cara tidak membuat visualisasi yang tidak terlalu terasosiasikan pada nilai-nilai Nusantara, melainkan lebih pada arah yang universal.

Secara tokoh, Nusa $V$ tetap mempertahankan nilai lokal melalui namanama para tokoh protagonisnya, beserta aspek-aspek peristilahan yang melekat padanya. Hal ini dilakukan agar para pembaca Nusa $\mathrm{V}$ lebih meminati komik ini berdasarkan nilai-nilai ke-Nusantara-an dan bukan mengacu hanya pada representasi visual semata. Istilah-istilah yang berasal dari Bahasa Sansekerta, yang notabene akrab dengan tradisi Hindu Nusantara, dimunculkan untuk memperkuat nilai-nilai Nusantara dalam komik Nusa V.

\section{PERNYATAAN PENGHARGAAN}

Penulis mengucapkan terima kasih kepada Indra Arista yang telah meluangkan waktu wawancara melalui surel (indra.arista@gmail.com) tanggal 6 Mei 2019.

\section{DAFTAR PUSTAKA}

Ahmad, Hafiz dkk. 2006. Histeria! Komikita. Elex Media Komputindo. Jakarta. 
Bancroft, Tom. 2006. Creating Character with Personality. New York: WatsonGuptill Publications

Barthes, Roland. 2007. Membedah Mitos Mitos Budaya Massa: Semiotika atau Sosiologi Tanda, Simbol, dan Representasi. Yogyakarta: Jalasutra

Barthes, Roland. 2012. Elemen-elemen Semiologi. Yogyakarta: Jalasutra

Boneff, Marcel. 1998. Komik Indonesia. Jakarta: Kepustakaan Populer Gramedia

McCloud, Scott. 1994. Understanding Comics. New York: William Morrow Paperbacks

McCloud, Scott. 2006. Making Comics. New York: William Morrow Paperbacks

Potts, Carl. 2013. DC Comics Guide to Creating Comics. New York: Watson-Guptill Publications

Rooswitha, Sheila \& Van Dongen, Peter. 2018. Indonesian Comics 1929-2017: A Chronological History. Jakarta: Kementerian Pendidikan dan Kebudayaan Indonesia

Swasty, Wirania. 2017. Serba Seri Warna: Penerapan Pada Desain. Bandung: PT. Remaja Rosdakarya 